\title{
Selenium Status of Very Low Birth Weight Infants
}

\author{
JAMES K. FRIEL, WAYNE L. ANDREWS, DAVID R. LONG, AND MARY R. L'ABBÉ \\ Departments of Biochemistry and Pediatrics, Memorial University of Nenfoundland. St. \\ John's, Newfoundland AIB $3 \times 99$ and Nutrition Research Division. Food Directorate, Ilealth Protection Branch. \\ Health and Helfare Canada, Ottawa, Ontario K1.1 OL2. Canada
}

\begin{abstract}
The selenium (Se) intake and status of 82 very low birth weight infants (birth weight $1110 \pm 286 \mathrm{~g}$, gestational age $29.2 \pm 3 \mathrm{wk}$, mean $\pm \mathrm{SD}$ ) was assessed at $36.3 \pm 3$ postconceptional wk, at $40.1 \pm 4$ wk (hospital discharge), and at $3,6,9$, and $12 \pm 0.75$ mo corrected for gestational age. Infants were fed formula containing 0.13 $\mu \mathrm{mol} / \mathrm{L}(10 \mu \mathrm{g} / \mathrm{L}) \mathrm{Se}$. Se-dependent glutathione peroxidase activity in red blood cells declined corresponding to low Se intakes $(\mu \mathrm{g} / \mathrm{kd} / \mathrm{d})$ for the first $6 \mathrm{mo}$. With increased consumption of solid foods, intakes of dietary Se and Sedependent glutathione peroxidase activity increased at 9 mo, suggesting that the earlier supply of Se was suboptimal. Se-dependent glutathione peroxidase activity and intakes of Se were lower in males than in females $(p<0.05)$. We suggest that infant formulas should probably contain $0.26-0.33 \mu \mathrm{mol} / \mathrm{L}(20-25 \mu \mathrm{g} / \mathrm{L})$ Se, particularly those formulas consumed by very low birth weight infants. (Pediatr Res 34: 293-296, 1993)
\end{abstract}

\section{Abbreviations}

VLBW, very low birth weight

GSHPx, glutathione peroxidase

SeGSIPX, selenium-dependent glutathione peroxidase

ANOVA, analysis of variance

TPN, total parenteral nutrition

VLBW premature infants $(<1500 \mathrm{~g}$ birth weight) are at risk for selenium deficiency due to $l$ ) shortened gestation resulting in inadequate stores (1) compared with those of full-term infants, 2) possible diminished selenium absorption during early postnatal development (2), and 3) an extended period of rapid growth (3-5). We (6) and others (7-9) have shown that selenium intakes during unsupplemented TPN are inadequate and can lead to low serum selenium levels. Once TPN is completed, low intakes of selenium may continue during infancy because consumption of formulas based on cow's milk unsupplemented with selenium provide only incidental selenium from the protein source $(4,6$, $10)$. It has been shown that inadequate dietary selenium may lead to unrecognized problems in VLBW infants (7). Infants consuming breast milk will obtain higher levels of selenium (4, 10 ), and the bioavailability is also superior (11).

Selenium is an essential component of the enzyme SeGSHPx, which is a protective factor against tissue oxidative damage. VLBW infants are known to have lower blood levels of selenium and SeGSHPx than term infants, which may be a contributing

Received February 2, 1993; accepted April 26, 1993.

Correspondence: James K. Friel, Department of Biochemistry, Memorial University, St. John's, NFLD, Canada, A IB $3 \times 9$.

Supported by Health and Welfare Canada and Ross Laboratories. Publication no. 408 of the Bureau of Nutritional Sciences. factor in the greater susceptibility of their erythrocytes to oxidative stress (12). Although serum selenium levels have been used to assess selenium status $(9,10)$, measurement of enzyme activity may be more informative of long-term status because the enzyme is a functional indicator of selenium status $(4,5)$. Because low intakes of selenium are a risk in this population, we monitored the selenium status of a group of VLBW infants during the first year of life, as part of a larger study involving zinc supplementation (13)

\section{MATERIALS AND METHODS}

Subjects. Eighty-two VLBW infants (mean birth weight 1110 $\pm 286 \mathrm{~g}$; mean gestational age $29.2 \pm 3 \mathrm{wk}$, mean $\pm \mathrm{SD}$ ) were recruited for this study from the neonatal intensive care units of the Dr. Charles A. Janeway Child Health Centre, the Grace General Hospital, and St. Clare's Mercy Hospital in St. John's, Newfoundland. The study was conducted prospectively in double-blind fashion after approval from the Faculty of Medicine Human Investigations Committee. All infants treated in these centers between June 1, 1984 and June 1, 1988 were eligible for the study if they were $<1500 \mathrm{~g}$ at birth. Infants were excluded if they had severe bronchopulmonary dysplasia that required more than 2 weeks of oxygen therapy, hydrocephalus, liver dysfunction, any congenital malformations, or were breast fed.

The gestational age of the infants was calculated from the last menstrual period of the mother and was also determined by the Dubowitz method (14). If there was a discrepancy of more than 2 wk between the two assessments, the latter method was used Size for gestational age was considered appropriate if the birth weight fell within 2 SD of median weight for gestational age according to the growth curves of Lubchenco et al. (15).

Approximately $85 \%$ of parents of eligible infants consented to enroll their infants. Of the 85 infants, two infants died during their hospital stay and one infant was removed to a hospital in another province, leaving 82 infants for whom data were available at discharge.

All infants received uniform management as established in their respective neonatal intensive care units and were fed a premature special care formula (Special Care, Ross Laboratories, Columbus, $\mathrm{OH}$ ) containing $24 \mathrm{kcal} / \mathrm{fl} \mathrm{oz}$ until they could tolerate a formula containing $20 \mathrm{kcal} / \mathrm{fl} \mathrm{oz}$. At a mean postconceptional age of $36.3 \pm 3 \mathrm{wk}$, infants received either $l$ ) infant formula with whey and supplemental zinc/copper drops $(n=29), 2)$ infant formula with whey and water drops $(n=27)$, or 3$)$ an experimental low birth weight formula $(n=26)$. All infants were fed ad libitum.

Upon discharge from hospital, study formula and drops were provided monthly for $5 \mathrm{mo}$. After that time, parents were responsible for purchasing their own formula. All formulas were fortified with iron at $233 \mu \mathrm{mol} / \mathrm{L}(13 \mathrm{mg} / \mathrm{L})$ and contained approximately $0.13 \mu \mathrm{mol} / \mathrm{L}(10 \mu \mathrm{g} / \mathrm{L})$ selenium (4). All formula was donated by Ross Laboratories in 32-oz ready-to-feed cans; 
who suggest that $2.5 \mu \mathrm{g} / \mathrm{kg} / \mathrm{d}$ is too low for these infants, who are born with low stores. We suggest that formulas for VLBW infants contain $0.26-0.33 \mu \mathrm{mol} / \mathrm{L}(20-25 \mu \mathrm{g} / \mathrm{L})$ selenium. Supplementation at this level would provide $3-4 \mu \mathrm{g} / \mathrm{kg} / \mathrm{d}$, well below the conservative upper limit of $8 \mu \mathrm{g} / \mathrm{kg} / \mathrm{d}$ suggested by Litov and Combs (4). In addition, these levels are similar to those reported in breast milk consumed by premature infants (10). Further research is needed to establish the optimal level of selenium fortification required to prevent the decline seen in erythrocyte SeGSHPx in the present study. This study suggests that the maintenance of erythrocyte SeGSHPx activity may be the best parameter to determine the optimal level of selenium fortification for these infants.

Acknowledgments. The authors thank the nurses and physicians for their help. We are especially grateful to the parents for their cooperation.

\section{REFERENCES}

1. Bayliss PA, Buchanan BE, Hancock RGV, Zlotkin SH 1985 Tissue selenium accretion in premature and full-term human infants and children. Biol Trace Element Res 7:55-61

2. Schanler RJ, Picciano MF 1991 Selenium and the very-low-birth-weight infant. J Pediatr Gastroenterol Nutr 13:123-124

3. Hambidge KM 1989 Trace element requirements in premature infants. In: Lebenthal E (ed) Texibook of Gastroenterology and Nutrition in Infancy, 2nd Ed. Raven Press, New York, pp 393-401

4. Litov RE, Combs GF 1991 Selenium in pediatric nutrition. Pediatrics 87:339351

5. Combs GF, Combs SB 1986 The Role of Selenium in Nutrition. Academic Press, Orlando, FL

6. Friel JK, Gibson RS, Peliowski A, Watts JL 1985 Selenium and chromium intakes of very low birthweight pre-term and full-term infants during the first year of life. Nutr Res 5:1175-1184

7. Lockitch G, Jacobson B, Quigley G, Dison P, Pendray M 1989 Selenium deficiency in low birth weight neonates: an unrecognized problem. J Pediatr 114:865-870

8. Huston RK, Jelen BJ, Vidgoff J 1991 Selenium supplementation in lowbirthweight premature infants: relationship to trace metals and antioxidant enzymes. J Parenteral Enteral Nutr 15:556-559

9. Amin S, Chen SY, Collipp PJ, Castro-Magana M, Maddaiah VT, Klein SW 1980 Selenium in premature infants. Nutr Metab 24:331-340

10. Smith AM, Chan GM, Moyer-Mileur LJ, Johnson CE, Gardner BR 1991 Selenium status of preterm infants fed human milk, preterm formula, or selenium-supplemented preterm formula. J Pediatr 119:429-433

11. Kumpulainen J, Vuori E, Siimes MA 1984 Effect of maternal dietary selenium intake on selenium levels in breast milk. Int J Vitam Nutr Res 54:251-255

12. Shaw JC 1982 Iron absorption by the premature infant. Acta Paediatr Scand Suppl 299:83 89
13. L'Abbe M, Friel JK 1992 Copper status of very low birthweight infants. Pediatr Res 32:183-188

14. Dubowitz LM, Dubowitz V, Goldberg C 1970 Clinical assessment of gestational age in the newborn infant. J Pediatr $1: 1-10$

15. Lubchenco LO, Hansman C. Boyd E 1963 Intrauterine growth as estimated from liveborn birthweight data at 24 to 42 weeks of gestation. Pediatrics 32:793-800

16. Nutrition Committee, Canadian Pediatric Society 1979 Infant feeding. Can J Pub Health 70:376-385

17. Beutler E 1975 Red Cell Metabolism. A Manual of Biochemical Methods, 2nd Ed. Grune and Stratton, New York, pp 11-12

18. Paglia DE, Valentine WN 1967 Studies on the quantitative and qualitative characterization of erythrocyte glutathione peroxidase. J Lab Clin Med 70:158-168

19. L'Abbe MR, Fischer PWF, Campbell JS, Chavez ER 1989 Effects of dietary selenium on DMBA-induced carcinogenesis in rats fed a diet high in mixed fats. J Nutr 119:757-765

20. Nie NH, Hull CH, Jenkins JG, Steinbrenner K. Bent DH 1975 Statistical Package for the Social Sciences. McGraw-Hill. New York

21. Food and Nutritional Board, Commission on Life Sciences, National Research Council 1989 Trace elements. In: Recommended Dietary Allowances, 10th Ed. National Academy Press, Washington, DC

22. Casey CE Hambidge KM 1985 Trace minerals. In: Tsang RC (ed) Vitamin and Mineral Requirements in Preterm Infants. Marcel Dekker, New York, pp $165-170$

23. Gropper SAS, Anderson K, Landing WM, Acosta PB 1990 Dietary selenium intakes and plasma selenium concentrations of formula-fed and cow's milkfed infants. J Am Diet Assoc 90:1547-1550

24. Litov RE, Sickles VS, Chan GM. Hargett IR, Cordano A 1989 Selenium status in term infants fed human milk or infant formula with or without added selenium. Nutr Res 9:585-596

25. Rudolph N, Preis O, Bitzos EI, Reale MM, Wong SL 1981 Hematologic and selenium status of low-birth-weight infants fed formulas with or without iron. J Pediatr 99:57-62

26. L'Abbe MR, Collins MW, Trick KD, Laffey PJ 1992 Glutathione peroxidase activity in a healthy Canadian population. Trace Elem Med 9:45-53

27. Gross S 1976 Hemolytic anemia in premature infants: relationship to vitamin E, selenium, glutathione peroxidase, and erythrocyte lipids. Semin Hematol 13:187-199

28. Friel JK, Andrews WL, Matthew D. Cornel A, Cox M, Skinner C 1990 Intakes of iron in Canadian very low birthweight infants. Can Med Assoc J 143:733739

29. Sluis KB. Darlow BA. George PM, Mogridge M, Dolamore BA, Winterbourne C 1992 Selenium and glutathione peroxidase levels in premature infants in a low selenium community (Christchurch. New Zealand). Pediatr Res 32:189-194

30. Friel JK, Gibson RS, Peliowski A, Watts JL 1984 Serum zinc, copper and selenium concentrations in pre-term infants receiving enteral nutrition or parenteral nutrition supplemented with zinc and copper. J Pediatr 104:763767

31. Ewan RC 1976 Effect of selenium on rat growth, growth hormone and diet utilization. J Nutr 106:702-709

32. Ehrenkranz RA, Gettner PA, Neili CM. Sherwonit EA, Williams JE, Ting BTG, Janghobani M 1991 Selenium absorption and retention by very-low birth-weight infants: studies with the extrinsic stable isotope tag ${ }^{74} \mathrm{Se}$. Pediatr Gastroenterol Nutr 13:125-133 